\title{
The Place and Meaning of Suffering in Evangelical Theology ${ }^{1}$
}

\author{
Prof. Dr Godfrey Harold \\ Cape Town Baptist Seminary \\ Research Associate, Stellenbosch University \\ South Africa \\ Email: godfrey@ctbs.org.za \\ https://orcid.org/0000-0002-6609-9651 \\ https://doi.org/10.46222/pharosjot.102.022
}

\begin{abstract}
The Evangelical view of God is rooted in Orthodox Theology. The article posits that it is within the classical understanding of God that Christians can find their best resources for dealing with the problem of evil from theological, practical and even philosophical perspectives.

The present suffering that COVID-19 has brought to the world requires us to answer the question, 'what on earth is God doing?' With over two million officially recorded deaths in the world and over 63000 deaths in South Africa, the present suffering requires an investigation on one of the most serious objections to a belief in a loving God. In this article, attention is given to how Evangelicals understand the implications, meaning and relevance of suffering. In developing a theology and meaning of suffering, I propose the approach that is rooted in the classical understanding of God is best suited to address this dilemma. Focusing on the works of Augustine, and Evangelical theologians, an Evangelical Theology on the meaning and relevance of human suffering which includes suffering as non-punitive and punitive is developed by concluding that God allows evil and punishment for development and discipline.
\end{abstract}

Keywords: God, evangelical, non-punitive suffering, punitive evil, evangelical, meaning

\section{Introduction}

The problem of evil is regarded as one of the most severe objections to theism and Christianity. In The Brothers Karamazov, Dostoyevsky (2019:215) states, "the earth is soaked from its crust to the centre with the tears of humanity". The cries of humanity have constantly been a challenge to the church to reconcile the attributes of God's knowledge, power and goodness with all the suffering in the world. Richard Dawkins, an atheist, would use the suffering of this world to conclude that there is no God. In trying to deal with the problem of evil, Boyd, in his book Is God To Blame? (2003: 21) asserts: "The most important aspect of faith is our mental picture of God. The way we envision God may be reflected in the theology we articulate." In articulating a picture of a limited God, open theism leaves suffering people with a God who is not cannot deal adequately with evil and suffering. This image thus distorts the concept of God. In this article, I shall discourse with Augustine, Evangelical theologians and Scripture to develop an Evangelical Theology on the meaning and relevance of human suffering which includes suffering as non-punitive and punitive.

\footnotetext{
${ }^{1}$ Part of the article is formulated from my PhD under the supervision of Prof. E Conradie, University of Western Cape.
} 
The Evangelical view of God, Harold (2021) asserts, finds its understanding of God's attributes rooted in Orthodox Theology. In this article, I shall show that it is within the classical understanding of God, that Christians are able to find their best resources for dealing with the problem of evil from theological, practical and even philosophical perspectives. Evil is categorized as "moral" or "natural" evil. The first refers to the wrongful action of human beings. On the other hand, natural evil includes pain and suffering that are not attributable to immorality: earthquakes, famine, flooding, etc. To define evil, then, is no easy task. St. Augustine, On the nature Good", maintains that evil is the "absence of good". Following a similar argument (in Summa Theologia Question 48. 1\&2), Aquinas writes: "Being and perfection of any nature are good. Hence it cannot be that evil signifies being or any form or nature. Therefore, it must be that the name of evil is signified [by] the absence of good. For since being, as such, is good, the absence of one implies the absence of the other." Thus, evil can be defined as a departure from the way things ought to be, whether morally as in the case of sin, or naturally as in pain and suffering. Therefore, from a practical perspective, there arises difficulty relating to God, given the abiding presence of evil in our lives and the world. How can one trust a God who allows so much injustice and suffering to continue? I shall demonstrate that the best strategy for dealing with this type of question arises from a classical view of God rather than that of open theism.

Helm (1993:193) observes that to address the problem of evil, one must reflect on the nature of evil, its origin and character. Thus, using the biblical data, evil is not to be identified with the body or with certain places, but its source is in the human will, in rebellion against and in a departure from God's rule (1John. 3:4). The mystery is that those God created as good defected from that goodness, evil being instigated by satanic influences which alienate people from their Redeemer who embraces them once they atone (Quantz, 1994; Nicolaides, 2010).

\section{An Evangelical perspective on evil and suffering}

Evangelicalism begins theologically with the sovereignty of God: the transcendent, personal, infinite Being who created and rules over heaven and earth. God actively identifies with the suffering of God's people, is accessible to them through prayer and has by His sovereign free will devised a plan whereby creatures may be redeemed. Evangelicals understand natural evil and suffering as a result of the disobedience of Adam. Adam and Eve, while still sinless, are placed in an idyllic garden, where they live in a happy relationship with their creator and creation. The "day" they disobey God, they commit moral evil (Genesis 3). In trying to articulate the nature, essence or identity of evil, McArthur (2000), in a sermon on "The Origin of Evil", gives a very clear understanding of how Evangelicals understand evil by explaining that to disobey God was to initiate evil. Evil is not the presence of something. Evil is the absence of righteousness. You cannot create evil because evil does not exist as a created entity. It does not exist as a created reality. Evil is a negative. Evil is the absence of perfection. It is the absence of holiness. It is the absence of goodness. It is the absence of righteousness. Evil became a reality only when creatures chose to disobey.

McArthur (2000) further explains that evil is not a created thing. Evil is not a substance. Evil is not an entity. Evil is not a being. Evil is not a force. Evil is not some floating spirit. Evil is a lack of moral perfection. God created absolute perfection. Wherever a lack of that exists, sin exists. Furthermore, that cannot exist in the nature of God or in anything that God makes. Evil comes into existence when God's creatures fall short of the standard of moral perfection. Evangelicals, like Aquinas, reject the idea that God is the author or the cause of evil, while at the same time to agree that God did not create all things is to deny the sovereignty of God.

\footnotetext{
${ }^{2}$ See http://www.newadvent.org/fathers/1407.htm
} 
Like St. Augustine, evangelicals respond that evil is not a thing or a substance that can be created. It is instead the lack of a good thing that God has made. Therefore, evil is a deprivation of some particular good. The essence of the position can be stated in the following way:

God created every substance.

Evil is not a substance (but a privation in a substance)

Therefore, God did not create evil.

Evil is not a substance but a corruption of the good substance that God made. It exists only in another but not by itself. Thus, evangelicals understand the origin of evil due to creatures using their free will to disobey God. Therefore, it can be argued that evangelicals follow St, Augustine or the classical understanding of the origin of evil.

However, another important part of evangelical faith is that God cares for us. The details and direction of our lives are under the purposeful control of God, who uses suffering to build character and therefore makes it worthwhile (Romans 8:27). As recounted in the book of Genesis, the life of Joseph provides evangelicals with a vivid portrait of how moral evil can rebound for the greater good. It should also be noted that evangelicals do not presume to be able to explain things. Admittedly, some moral evils are so horrific that they defy the imagination, and one can only ask, "Why"? Evangelicals confess that no matter how impossible a situation might seem, it is always redeemable, for God's power has no limits. To limit God's power because of our limited and finite understanding would be presumptuous and arrogant. Thus, evangelicals would have a fortiori ('from the stronger') biblical ground for believing that God has good purposes in all moral evil and that we are just blind to or limited in our understanding of these purposes. The death of Jesus Christ on the cross shows how God can use the murder of Jesus to redeem humanity. Evangelicals understand that God is thus capable of redeeming the worst of all evils. Therefore, a fortiori argument is used to show that there are no acts "too evil" for God to redeem, thus bringing out the greater good. It then can be argued that there seems to be a combination of the theodicies of St. Augustine and St. Irenaeus within evangelicalism, both of whom explain evil and suffering without limiting the attributes of God.

\section{How do Evangelicals Resolve the Problem of Evil?}

To resolve the philosophical problem of evil, evangelicals propose an explanation as to why God would permit evil by merging the views of St. Augustine and St. Irenaeus. Harold (2009:210-216) suggests that we evangelicals should not ask "Why am I suffering?" but rather "What is the meaning of this suffering?" I propose that in this way, evangelicals are better able to give a reason for the evil and suffering in this world. Helm (1993:200) states that God could have prevented evil in the world by creating human beings who freely only choose to do that which is morally right, but God, who is omnipotent and omniscient, chose not to create such humans.

Evangelicals generally take the approach St. Augustine (Enchiridion XI) held to:

For the Almighty God, who, as even the heathen acknowledge, has supreme power over all things, being himself supremely good, would never permit the existence of anything evil among His works if God were not so omnipotent and good that he could bring good even out of evil (italics added).

Thus, St. Augustine asserts that God would not have allowed evil to occur unless he had not been able to bring good out of that evil. This is not the same as Irenaeus' view that states that God allowed evil to bring out good but rather that God uses evil to bring out good. Evangelicals do not hold to the view that God created evil but rather that its source is in the use of human 
will, in rebellion against and departure from God's rule, in lawlessness (1John 3:4). God created humanity as good and with free will, which deflected it from that goodness. Thus, evangelicals would concur with St. Augustine that God is not the cause of evil because God cannot be morally bad, and the problem of evil cannot be used to show that God is morally bad. So, while evangelicals assert that God allowed evil to occur in the world, those reasons for the suffering and evil are revealed to us in two possible ways, namely: through the greater good defence: punitive evil (justification) and the greater good defence: non-punitive evil (ethical). I shall deal with non-punitive evil first.

\title{
The Greater Good: Non-punitive Suffering
}

Evangelicals would argue that the justification for permitting suffering, which is necessary for producing a certain good, is simply that suffering produces these goods. The good that suffering produces outweighs the evil. This is an application of the theodicy of St. Irenaeus and John Hick. Although evangelicals would disagree that God's creation of the first human beings was not perfect, they would agree with St. Irenaeus that God allows evil to bring human beings into their perfect state.

\section{Suffering Builds Character}

Evangelicals would argue that there is justification for God to allow suffering as it is necessary to build character. The value of the good that suffering produces far outweighs the suffering itself. Evangelicals view as part of the Christian life through which the comfort of God can be experienced, and character is transformed. Thus, evangelicals justify the non-punitive approach to God's permitting of suffering by maintaining that it produces in everyone benefits that outweigh the evil and which logically would not have occurred if the evil had not occurred. Evangelicals understand that suffering comes only if God permits it and that God's purposes are accomplished through the suffering we experience. Thus, we understand evil as not aimless nor inflicted by fate. God's aim in allowing suffering is to encourage Christians not to rely on themselves but on the God, who delivered Jesus - and will deliver us. Clement (1994:24-24) interpreting Paul in 2 Corinthians. 1:8-9 writes:

\begin{abstract}
Paul is convinced that God's providence deliberately engineered his descent into abject despair. Doubt, uncertainty, and intellectual insecurity are experiences we pass through to discover faith. The opposite of faith, according to Paul, is not doubt but confidence "in the flesh" that one can cope on one's own; that one does not need the grace of God. The people who are farthest from the faith are those who are too sure of themselves. God had to teach even him, the great apostle, not to rely on himself, but "on God who raises from the dead".
\end{abstract}

Thus, evangelicals respond to suffering by focusing on God and remaining steadfast in hope during suffering because of who God is and what he is teaching us through suffering. Despite the pain that suffering brings, evangelicals also understand that suffering is part of the purifying process of the Christian life. Grudem (1988:78) comments that a refiner's fire image suggests that such suffering purifies and strengthens the Christian. Marshall (1997:157) states:

\begin{abstract}
Are we to say that God intends his people to suffer? Hard though it may seem, the answer to this question is affirmative. It was God's will that Christ should suffer to redeem his people, and Christ was obedient to that will. To be sure, the need arose only because of the evil in the world, but in the world where evil exists, defeat is possible only through suffering. It is right to say that God's will for us is suffering because there is no other way that evil can be overcome. It is not a sign of God's lack of love or concern for us when we suffer. Those who suffer can confidently place themselves in the care of God.
\end{abstract}

The Christian who suffers has to trust God, rely on his perfect will, entrust their life to God. Evangelicals understand suffering as something to be expected because, through suffering, God fulfils his divine plan by moulding his people and demonstrates his glory 
when Christians persevere and are triumphant by being faithful to God. This perseverance amid suffering brings an understanding of who God is, but perseverance also builds character and character hope. McGrath (1995b:73) states that suffering gets rid of the dross of all the worldly support we foolishly invent for our faith. Through suffering, we come to learn that God is our strength, sustenance and life and hope.

\title{
Suffering and Hope
}

Suffering and hope are interrelated. McGrath (1995b:50) observes a strong sense in which the only way that leads to hope indeed passes through suffering. I define hope as the unshuttering confidence that God is faithful to do all that he has promised. Hope is sensible in the light of God's character, and suffering then finds meaning and is endurable in the light of hope.

Thus, hope lives between the "now and the not yet". How then do evangelicals know that what hope looks forward to will come to pass? I suggest that hope is inseparably linked to God's promises. Bruce (1994:130-131) states that "our hope is fixed in the general order of things, where the promises of God will be made good to his/her people in perpetuity". It is this hope in God, and who he is that spurs us on to trust him while we participate in and work through the pain and suffering, knowing that God will ultimately deliver us from our predicament. Because Evangelicals view the Bible as trustworthy for faith and life. It gives the evangelical believer unshakeable hope to know that God has promised to be with us when we pass through the raging fires and deep suffering and affliction. It is the promise that God will not forsake us but will remain with us to the very end (Hebrews 13:5; Matthew 28:20). God's promises become an anchor for the soul, firm and secure. Jewett (1981: 112) points out that "hope is the anchor to the soul, not in the sense of guaranteeing the immortality of the soul, but in the sense of providing a stabilizing effect on the whole person; being a basis for mental health in a world that seems to defy sanity. It holds firm and safe when everything deteriorates."

\section{Suffering and the Cross}

The framework of evangelical response to suffering is based on the cross. Evangelicals thus understand this hope more clearly, as seen through the cross. Suffering and the cross go together. Only within the context of the cross is the basis of the evangelical response to suffering provided. Zacharias (1998:216-217) correctly noted that:

\begin{abstract}
When we come to Jesus at the cross, where love, holiness and suffering combine, we find both the answer to why we suffer and the strength to live this mortal frame for him, as we come to the cross and from there live our lives for him; we make the extraordinary discovery that the cross and the resurrection go together.
\end{abstract}

The cross then becomes the focus where evil, innocent suffering, malice and human suffering is portrayed at its climax. For in the cross, we see the wrath of God on the one hand, and on the other hand, we see his love and righteousness revealed. The cross is the manifestation of God's power, identification, participation, endurance and transformation. For in the cross lies the overwhelming and ultimate victory over evil. The understanding of the cross and our solidarity with the suffering of Christ combined with the perfectly redemptive nature of his work guarantee that none of our pain or sorrow is wasted. The whole of Christ suffering achieved good, and so would our suffering. Our suffering and sharing in pain as Christ did on the cross are valuable for the direct knowledge of God that it imparts. Adam (1990:219) states that "our deepest suffering as much as our highest joys may themselves be direct vision into the inner life of God". From this perspective, the pain and suffering endured is yet another portal into the mind and glory of God. Adam (1990:218) again notes:

The good of the beatific vision, face to face intimacy with God, is simply 
incommensurate with any merely non-transcendent good or ills a person might experience. Thus, the good of the beatific face-to-face intimacy with God would engulf even the horrendous evils humans experience below.

To know the beauty of the Lord intimately is an incomparable good, and suffering is a vehicle for closer divine acquaintance. Many Evangelicals will report the experience of drawing closer to God came through their trials.

Thus, for evangelicals, God remains the sovereign Creator and Lord of history who is not apathetic to the world or humanity; God is not simply a transcendent power of destiny to whom one must submit. God is not an impersonal sphere of all being in one sense of pantheism, in which the individual forgetting the joy of suffering is lost to himself; but rather God is a loving God who offers himself in Christ Jesus. God in Christ is a sympathetic God who understands our pain and suffering. In Christ, the theodicy question arises between God the Father/Mother and Christ when Jesus Christ cries out: "My God, My God, why have you forsaken me" (Mark 15:34). In the resurrection of Christ, one who dies in the space of the sinner and one who makes the ungodly righteous, the theodicy between God and Jesus Christ is finally completed. In this, evangelicals see from the perspective of the cross that suffering is overcome as we live through the power of Christ's resurrection. The cross is the ultimate symbol of God's victory over sin and suffering. Therefore, on the cross, God has done something about our suffering in the present and will do something about suffering in the future. King (1963:46) rightfully observes that evangelicals, therefore, see the cross as a magnificent symbol of love conquering suffering and light overcoming darkness. The suffering we face prepares us for glory when suffering and evil shall ultimately be defeated.

Because God knows everything, he knows the good purpose for all evil, even if we do not. Since God is both omniscient and good, he has a good purpose for everything. Therefore, this can be stated in the following way:

\section{An omniscient and good God has a good purpose for everything.}

There is some evil for which we see no good purpose.

Therefore, there is a good purpose for all evil, even if we do not see it.

The fact that human beings do not see the purpose for some evil does mean there is none. This inability to know the purpose for evil does not disprove God's omniscience, omnipotence and goodness: it merely reveals our ignorance. Therefore one occasions suffering can be a part of God's loving parental discipline that he uses on his children in holiness (Hebrews 12:511). God can at times appoint suffering for the strengthening, purification and spiritual growth of his children (e.g. Romans 5:3-5; James 1:2-4). Suffering and pain can expose human frailty and weakness so that the strength of God shines all the more gloriously.

\section{Punitive Suffering}

Evangelicals also understand that God uses moral evil, evil actions flowing from human decisions permitted by God, in part as punishment for other evils. St. Augustine (as cited in Helm 1993:209) claimed that "Vices in the soul arise from its own doing, and the moral difficulty that ensures that vice is the penalty which it suffers". At the same time, God allows evil, like St. Augustine evangelicals do not see God as being the author of evil. St Augustine (as cited in Helm 1993: 209) also states that if one believes that God is good, God cannot do evil. God assigns rewards to the righteous but judgment to the wicked, punishing those who endure them.

If God is not the author of evil, it follows that the one reason God allows suffering for only one reason is that the justice of God might be upheld. Therefore, it can be concluded that God ordains suffering as a punishment for that first evil. Why then does God allow this evil in the 
first place since it is presumably perfectly consistent with the justice of God that no moral evil should be permitted? St Augustine proposed an answer that finds agreement within evangelical circles (Grudem, 1994; Erickson, 1998) because human beings using their free will to make an immoral decision, as were in the first evil in the Garden of Eden that God allows suffering to be. Thus evangelicals understand that some suffering (not all) is punishment for sin and God bringing judgement on those opposed to him (e.g. Isaiah 10:5- 19, 2 Thessalonians 1:6). Therefore, it is consistent within the evangelical tradition to argue that God allows acts of free will, some of which are evil. However, God also ordains other evil, which is punishment for the evil done. Thus God allows suffering as punishment so that justice can reign in the universe as a moral order.

\section{Conclusion}

Therefore, it can be concluded that God allows evil and punishment for development and discipline. Helm (1993:215) states in Christ both are linked, in that his atonement is both the enduring of punishment for moral evil and the source of renewal through which the character of God is fully manifested. my conclusion is that the only genuine source of comfort and hope for evangelicals who are grappling with suffering and evil is a God who knows the future exhaustively (Harold, 2020) and is not surprised by our suffering; a God who does not change in word and promise; and a God who has the power to act in any given situation. It involves our trusting in God who knows when to intervene to take away the suffering, and who is assuredly working out his/her good purposes wisely and efficaciously for his/her children. In this understanding of God one can rejoice and put one's trust and ultimate hope, even when we suffer.

\section{References}

Adams, M.M. (1990). Horrendous evil and the goodness of God. In MM Adams and RM Adams (Eds.) The Problem of Evil, Oxford University: Oxford, 209-221.

Adams, R. (1987). The Virtue of Faith and Other Essays in Philosophical Theology, Oxford University Press: Oxford.

Aquinas, (nd). Summa Theologia Question, 48. 1\&2. [Available online at http://www.newadvent.org/summa/1048.htm]. (Retrieved June 20 2021).

Augustine, (1979). City of God. In P Schaff (Ed) The Nicene and Post Nicene Fathers, Vol. II. Eerdmans: Grand Rapids, 1-511.

Augustine, (1979). Confessions. In P Schaff (Ed) The Nicene and Post Nicene Fathers, Vol. I, Eerdmans: Grand Rapids, 45-208.

Augustine, (1979). Writings against the Manichaeans. In P Schaff (Ed.) The Nicene and Post Nicene Fathers, Vol. III, Eerdmans: Grand Rapids, 41-368.

Augustine, (nd.) On the Nature of Good. [Available online at http://www.newadvent.org/fathers/1407.htm]. (Retrieved on July 10 2021).

Augustine, (nd.) Enchiridion Chapter 11. [Available online at https://www.leaderu.com/cyber/books/augenchiridion/enchiridion01-23.html].(Retrieved on July 15 2021).

Barth, K . (1957) . Church Dogmatics II.1: The Doctrine of God, Edited by G.W. Bromiley and TF Torrance, T\&T Clark: Edinburgh. 
Boyd, G. (1992). Trinity and Process, Peter Lang: New York.

Boyd, G. (2000). God of the Possible: A Biblical Introduction to the Open View of God, Baker Book House: Grand Rapids.

Boyd, G. (2001). Satan and the Problem of Evil: Constructing a Trinitarian Warfare Theodicy, InterVarsity Press: Downers Grove.

Boyd, G. (2003). Is God to Blame? Beyond Pat Answers to the Problem of Evil, InterVasity Press: Downers Grove.

Bruce, F.F. (1994). The Epistle to the Hebrews, Eerdmans: Grand Rapids.

Clement, R. (1994). The Strength of Weakness, Christian Focus: Guernsey.

Dostoyevsky, F. (2019). The Brothers Karamazov, Trans by C. Garreth, Digiread Publication: Overland Park.

Erickson, M.J. (1988). Christian Theology, Grand Rapids: Baker.

Grudem, W. (1994). Systematic Theology: An Introduction to Biblical Doctrine,Zondervan: Grand Rapids:

Harold, G. (2009). Suffering to Worship: A Pastoral Challenge, The South African Baptist Journal of Theology, 18, 210-216.

Harold, G. (2013). An Evangelical discourse on God's response to suffering: A critical assessment of Gregory Boyd's open theism. Unpublished PhD Dissertation, University of Western Cape.

Harold, G. (2020). An interlocutory engagement on Barth's Shadow Side of Creation and Boyd's Warfare Theodicy as it relates to the origin of natural evil. [Available online at https://www.pharosjot.com/uploads/7/1/6/3/7163688/article_35_vol_101_2020_stellenbos ch.pdf]. (Retrieved July 20 2021).

Harold, G. (2021). The Doctrine of God's Immutability: A Literary Investigation. [Available online at https://www.pharosjot.com/uploads/7/1/6/3/7163688/article_19_vol_102_2021_.pdf (Retrieved July 20 2021).

Helm, P. (1993). The Providence of God, InterVasity Press: Illinois.

Hick, J. (1966). Evil and the God of Love. Macmillan: London.

Irenaeus, (1978). Irenaeus Against Heresies. In A. Roberts and J. Donaldson (Eds.) The Ante Nicene Fathers Vol. I. Eerdmans: Grand Rapids, 309-567.

Jewett, R. (1981). Letters to the Pilgrim, Pilgrim: New York:

King, M.L. (1963). Strength to Love, Harper and Row: New York.

Marshall, H.I. (Ed). (1977). New Testament Interpretations, Paternoster Press: Great Britain. McArthur, J. (2000). The Origin of Evil [Available online at 
http://www.jcsm.org/StudyCenter/john_macarthur/90-235.htm ](Retrieved on July 10 2021).

McGrath, A.E. (1995a). Evangelicalism and the Future of Christianity, InterVarsity Press: Downers Grove.

McGrath, A.E. (1995b). Suffering and God. Zondervan: Grand Rapids.

Nicolaides, A., (2010), 'The Laos tou Theou - an orthodox view of the "people of God"', HTS Teologiese Studies/Theological Studies, 66(1)

Quantz, N.R. (1994). An Investigation of Satanic Influences Upon Physically, An Investigation of Satanic Influences Upon Physically, Emotionally, and Spiritually Disturbed Christians: Selected Case Studies, Andrews University Graduate Research.

Zacharias, R. (1998). The Cries of the Heart: Bringing God Near When He Feels So Far. Word: Nashville. 